ISSN 2080-1653

DO1 10.24917/20801653.344.8

\author{
MARIYA VIKHOREVA \\ Irkutsk State Transport University, Irkutsk, Russia \\ ANATOL JaKoBSON \\ Irkutsk State Transport University, Irkutsk, Russia
}

\title{
Socio-economic conditions as a factor of revealing cities' marketing potential
}

\begin{abstract}
The object of the study are the socio-economic conditions of cities as the basis of marketing potential. The purpose of the study is to identify the role of socio-economic conditions in revealing the marketing potential of cities. The main methods used for the study are matching, comparison, ranking. Our conclusion is that socio-economic conditions cannot always be perceived as the basis for revealing the marketing potential of a city, which is proved by independent studies of the authors, as well as by the analysis of data obtained in the course of other studies. It was possible to establish that socio-economic conditions do not guarantee permanent population growth for cities: the affordability of a basic set of goods and services, a competitive level of income, the availability of higher education institutions and the saturation with health and cultural facilities are not necessarily highly rated by real and potential local residents. This allows us to speak about the need for marketing efforts to attract consumers of a territorial product (socio-economic conditions of a city), it is not enough to have any advantages - it is important to be able to draw attention to them, to ensure the formation of the necessary attitudes regarding the socio-economic conditions of life in cities. Therefore, we are speaking about the need to take into account the nature of consumer demand for the socio-economic conditions of cities and the use of the appropriate type of marketing. The authors have examined a number of examples of applying city types of marketing, such as conversion, incentive, supportive, synchromarketing, remarketing and demarketing.
\end{abstract}

Keywords: marketing; marketing of territories; marketing potential; ranking of cities; socio-economic conditions; types of marketing

Received: 4 January 2020

Accepted: 10 November 2020

\section{Suggested citation:}

Vikhoreva, M., Jakobson, A. (2020). Socio-economic conditions as a factor of revealing cities' marketing potential. Prace Komisji Geografii Przemysłu Polskiego Towarzystwa Geograficznego [Studies of the Industrial Geography Commission of the Polish Geographical Society], 34(4), 126-137. doi: 10.24917/20801653.344.8

\section{INTRODUCTION}

City marketing is a set of actions of the city community aimed at identifying and promoting their interests in order to fulfil specific tasks of socio-economic development of the city. In a broad sense, this is the promotion of the city's interests (Vizgalov, 2008). The success of this activity is largely determined by the motivation and initiative of 
local residents, which is well shown in the model of territory marketing complex 10C (Kuron, 1997), which reflects the need for systematic consideration of management technologies, public participation, and a client-oriented approach. The main client here is the local population.

This is the point at which the attention and the definitions of "marketing potential of a territory" are focused.

\section{MATERIAL AND METHODS}

Studying the marketing potential of cities, we relied on understanding this category in the framework of territories marketing, both by classic and latest specialists.

A recognised specialist in the field of territorial development, M. Porter is interested not so much in the concept itself as in its applied meaning, i.e. the possibilities for conducting an assessment. After all, his theory of territorial competitiveness is nothing more than an attempt to show what a territory is capable of, how attractive its products are to consumers. Here, again, we see a great attention to the domestic consumer - it is well known that one of the determinants of the "competitiveness rhombus" is the "domestic demand conditions" (Porter, 1993: 94)

For example, marketing potential of a territory is understood as a set of resources of the territory and its market opportunities that allow for the forming of and maximally satisfying the needs of the territory in goods and services in the process of socio-economic relations with its strategic development in the interests of the population (Tolstykh, 2013).

Besides, there exists a point of view that the marketing potential of a territory is the total ability of the socio-economic system to develop through fully meeting the needs of external and internal groups of consumers of the territory at the expense of existing and potential resources (Tselykh, 2016).

From the point of view of marketing, "economic potential" characterises the total integration capabilities of an economic entity to meet the needs of consumers as much as possible, taking into account the interests of the state as to rational attracting and using the resources (Kiryanova, Fedko, 2016).

Analytical review of the stages of development of basic concepts of marketing, allows to identify and classify the following approaches related to the study of the concept of "marketing potential":

- the target one;

- the resource one;

- the resultant one.

Thus, in accordance with the target approach, marketing potential is a reflection of the considered range of commercial and marketing tasks that the system is able to solve independently (meaning the absence of outside interference) with a high degree of economic efficiency. Within the framework of the resource approach, marketing potential of the territorial system is determined mainly by the effectiveness and level of state administration bodies control over the processes of socio-economic development of the territory. The resultant approach is determined by the return of resources used in production and consumption, namely, the amount of profit received (profit tax and value added), and consists in ensuring the break-even of production, economic and 
financial activities of all production units (legal entities, branches and representative offices) on the territory.

Common to all considered conceptual approaches of marketing to the definition of the term "marketing potential" is their orientation at the consumer, i.e. adaptation of production processes to the consumer's needs, expectations and requirements. In the framework of implementation of social marketing concept, the process of forming and developing the marketing potential of the socio-economic system of the region acquires a complex content, since it includes not only solving problems related to meeting all the needs of priority groups of resource consumers in the territory, but also preserving and maintaining high-quality environment (Fedorovich, 2019).

Speaking about the methods of our research, we have to admit that the most useful were the methods of comparison, since it is impossible to assign any specific amount of marketing potential: in practice, territories can only constantly increase it, in particular, due to socio-economic conditions.

We put forward a hypothesis that socio-economic conditions are a necessary factor for revealing marketing potential of a territory, but absolutely insufficient. Although everywhere the authorities and administrations of various territories set themselves this very task, completely forgetting that to increase the demand for territorial products in modern conditions, marketing efforts are also necessary.

\section{RESULTS}

\section{Arguments for the functioning and development of cities}

The marketing potential of cities, from our point of view, is primarily the ability to attract and retain the target consumer - the permanent population. Consolidation of the population in the territory, first of all, is provided due to social and economic conditions.

Socio-economic conditions, being the basis for attracting the population, include two aspects: the arguments of functioning and the arguments of prospects for development. The first aspect indicates the presence of socio-economic conditions that can meet the basic needs of a modern person in comfortable living - the availability of housing, roads, basic medical facilities, the level of public security and so on. The second aspect includes socio-economic conditions that can ensure the development of human potential and the needs that exceed the everyday ones, such as - an airport, higher education institutions, high-tech medical institutions and so on.

Let us consider the state of two aspects of the indicators of the cities included in the sample.

Arguments affecting the marketing potential of the territory can be divided according to the direction of dynamics and development, which has a favourable impact on the territory.

In terms of assessing the arguments for functioning of the territory, it is necessary to study the data on indicators such as "the cost of a fixed set of goods and services" and "the cost of housing", these are characteristics that have a great impact on the real and potential consumer.

In Irkutsk, these characteristics demonstrate values comparable with the cities in which the population number exceeds million. Therefore, it should not be surprising 
that this reduces the marketing potential of the city: the price is at the level of larger cities, this largely explains the outflow of young people to other cities. The only competitive advantage is the level of wages, but this fact is offset by difficulties in finding a job.

Figure 1. Arguments of functioning and prospects of development of cities

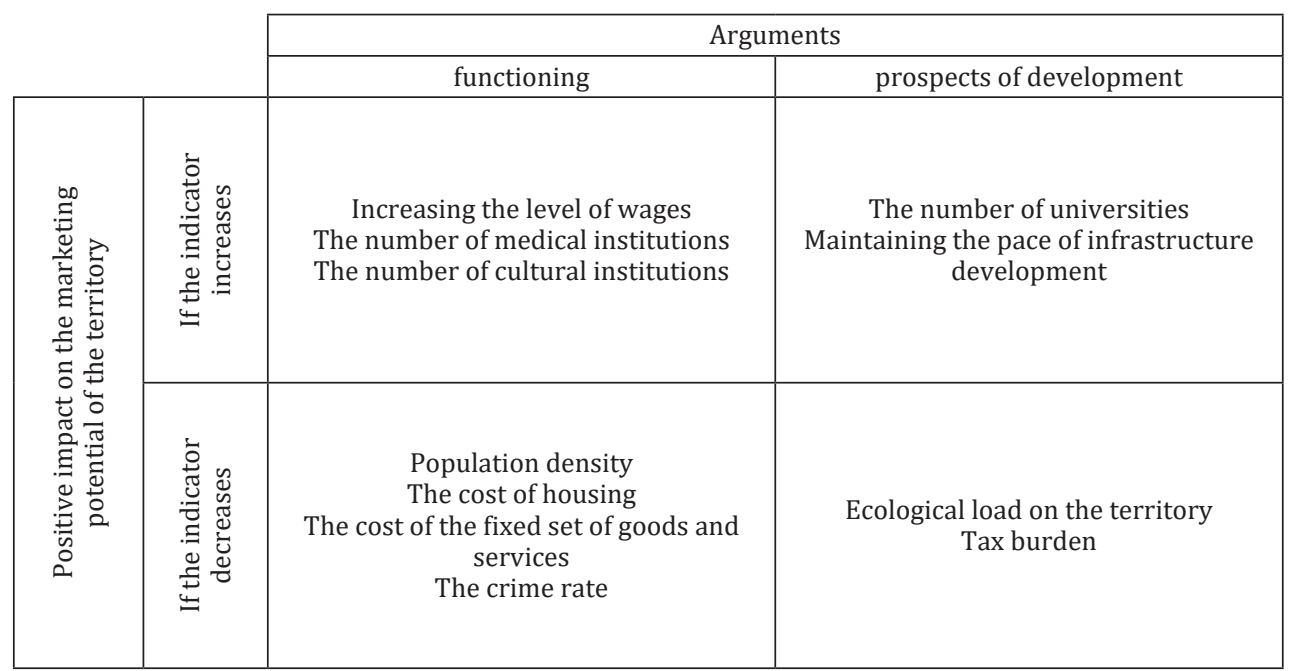

Source: authors' own work (2019)

Consider this situation in more detail.

\section{Comparative analysis of socio-economic conditions in several Russian cities}

The city of Irkutsk ranks 23rd in Russia in terms of population. It is one of the cities of Eastern Siberia, the capital of Irkutsk Oblast, a rather old city, now a major administrative, cultural, industrial, transport and scientific centre of the whole Eastern Siberia.

In 2003-2008, the population of Irkutsk has fallen. This is explained by both migration outflow and natural population loss. The implementation of programs aimed at reducing mortality, increasing life expectancy, and increasing fertility helped to change the demographic situation in the city since 2009 to 2015 . The outflow of population from Irkutsk has decreased and the inflow of labour force from other countries and regions is stimulated.

We conducted a comparative analysis of Irkutsk with the cities of Siberia, which have already crossed the threshold of the population of one million people (the data were gathered for 2014-2019). These are Novosibirsk, Omsk and Krasnoyarsk. Also Ufa and Volgograd in the European part of Russia were included in the list of studied cities in order to strengthen the comparative analysis.

According to statistics, of all these cities, the most populous city is Novosibirsk. The next are Omsk, Ufa, Krasnoyarsk and Volgograd. 
Table 1. Ranking of cities by economic indicators

\begin{tabular}{|l|c|c|c|c|}
\hline \multicolumn{1}{|c|}{ City } & Salary and wages & $\begin{array}{c}\text { Cost of the fixed } \\
\text { set of goods and } \\
\text { services }\end{array}$ & $\begin{array}{c}\text { Cost per square } \\
\text { metre of housing }\end{array}$ & $\begin{array}{c}\text { Ranking on this } \\
\text { group of indicators }\end{array}$ \\
\hline Irkutsk & 2 & 4 & 4 & 4 \\
\hline Novosibirsk & 4 & 5 & 5 & 5 \\
\hline Omsk & 4 & 1 & 1 & 6 \\
\hline Krasnoyarsk & 6 & 6 & 3 & $2-3$ \\
\hline Ufa & 1 & 2 & 6 & $2-3$ \\
\hline Volgograd & 4 & 3 & 2 & 6 \\
\hline
\end{tabular}

Source: website of the Federal state statistics service of Russia

Of the cities, in the most favourable position is Omsk, where the relatively low cost of housing and of fixed set of goods and services is accompanied by the high level of wages.

Table 2 jointly characterises the level of development of social infrastructure.

Table 2. Ranking of cities by social indicators

\begin{tabular}{|l|c|c|c|c|}
\hline \multicolumn{1}{|c|}{ City } & Universities & Medical institutions & Cultural institutions & $\begin{array}{c}\text { Ranking on this } \\
\text { group of indicators }\end{array}$ \\
\hline Irkutsk & 6 & 4.5 & 3 & 5 \\
\hline Novosibirsk & 1 & 4.5 & 1 & 1 \\
\hline Omsk & 2.5 & 1 & 5 & 2 \\
\hline Krasnoyarsk & 2.5 & 6 & 6 & 6 \\
\hline Ufa & 4 & 3 & 2 & 3 \\
\hline Volgograd & 5 & 2 & 4 & 4 \\
\hline
\end{tabular}

Source: website of the Federal state statistics service of Russia

Novosibirsk is the leader in the number of universities. But the numerical superiority of universities is due to a sufficiently high population compared to other cities. Irkutsk occupies the last position, where universities are 2 times less than in Novosibirsk, which is a proportion for the difference in the population of these cities. In general, Irkutsk universities meet the needs of the city for specialists with higher education.

As for the availability of medical facilities, the absolute number in Irkutsk is the least, but in relative terms the situation is better than in the cities-millionaires.

Next, consider the number of cultural objects as a characteristic of the arguments for the prospects of development of the territory.

A well-deserved first place in this rating belongs to Novosibirsk. As for the number of theaters and museums, it surpasses all the cities. In Irkutsk, there are two times fewer institutions than in Novosibirsk, providing services to provide the population with the opportunity to see performances and observe historical values. In Irkutsk, there are as many cinemas as in Novosibirsk. The last place in the ranking by the number of cultural institutions belongs to Krasnoyarsk.

When considering another key socio-economic condition, it is necessary to recognise that Irkutsk has the highest crime rate among the cities considered in this study (Table 3). Omsk is a relatively safe city. 
Table 3. The level of crime

\begin{tabular}{|l|c|}
\hline \multicolumn{1}{|c|}{ City } & Ranking on this indicator \\
\hline Irkutsk & 6 \\
\hline Novosibirsk & $4-5$ \\
\hline Omsk & 1 \\
\hline Krasnoyarsk & $4-5$ \\
\hline Ufa & 3 \\
\hline Volgograd & 2 \\
\hline
\end{tabular}

Source: website of the Federal state statistics service of Russia

From this comparative analysis, it is clear that Irkutsk is practically not inferior to the leading cities in terms of higher educational institutions, medical institutions and cultural facilities, i.e. the arguments for the prospects of development are quite well formed. Consequently, the marketing potential of socio-economic conditions is high. To realise the existing marketing potential, it is necessary to focus on the possibilities of promoting the city of Irkutsk as a territory for permanent residence.

However, if we pay attention at the dynamics of the population of these cities, we find an interesting fact: there is no direct link between the rating position of socio-economic conditions and the growth of the population of cities (Table 4).

Table 4. Comparison of the rating of the studied cities and population growth rates

\begin{tabular}{|l|c|c|}
\hline \multicolumn{1}{|c|}{ City } & Rating & Population growth rate for 5 years, \% \\
\hline Omsk & 1 & -0.77 \\
\hline Ufa & 2 & 1.59 \\
\hline Volgograd & 3 & -0.45 \\
\hline Novosibirsk & 4 & 4.53 \\
\hline Irkutsk & 5 & 1.71 \\
\hline Krasnoyarsk & 6 & 4.72 \\
\hline
\end{tabular}

Source: website of the Federal state statistics service of Russia

It already allows to draw a conclusion that the marketing potential includes social and economic conditions, but, is not completely defined by them.

As a more extensive evidence base, let us turn to the study of the quality of life in Russian cities, which the Financial University under the government of the Russian Federation has conducted annually since 2014; in 2019, studies were conducted in 78 Russian cities with a population of more than 250,000 people.

The analysis is based on the opinions of residents about certain aspects of urban life:

1. Work of the services engaged in maintenance and repair of roads, public transport and traffic police,

2. Development of education and cultural infrastructure,

3. State of the housing stock and improvement of the city,

4. Work of local authorities,

5. Quality of medical care,

6. General assessment of the situation in the city. 
On the basis of the collected data, partial ratings were built for each of the directions, as well as the final rating of cities on the quality of life. The leaders in the overall rating of quality of life among large and medium-sized Russian cities are:

1. Kazan,

2. Grozny,

3. Tyumen,

4. Krasnodar,

5. Moscow,

6. Saint-Petersburg,

7. Irkutsk,

8. Ufa,

9. Kemerovo.

As you can see, two of the cities listed were present in our sample. Table 5 presents data on the dynamics of population change in the leading cities of the rating compiled by the Financial University under the government of the Russian Federation, except for data on the cities of Irkutsk and Ufa, which were presented earlier.

Table 5. Population growth rates in cities-leaders of the rating compiled by the Financial University under the Government of the Russian Federation in 2019

\begin{tabular}{|c|l|c|c|c|}
\hline $\begin{array}{c}\text { Position in the } \\
\text { ranking }\end{array}$ & \multicolumn{1}{|c|}{ City } & 2014 & 2018 & $\begin{array}{c}\text { Population growth } \\
\text { rate for 5 years, } \%\end{array}$ \\
\hline 1 & Kazan & 1190850 & 1243500 & 0.04 \\
\hline 2 & Grozny & 280263 & 297137 & 0.06 \\
\hline 3 & Tyumen & 679861 & 768358 & 0.13 \\
\hline 4 & Krasnodar & 951198 & 899541 & -0.05 \\
\hline 10 & Kemerovo & 544006 & 558662 & 0.03 \\
\hline
\end{tabular}

Source: website of the Federal state statistics service of Russia

The situation with the population growth rate of Krasnodar once again proves that it is not enough for the city to have good socio-economic conditions to attract the population. Socio-economic conditions do not allow to fully unleash the marketing potential.

Thus, in order to unlock the marketing potential of cities, it is necessary to work with its other components, such as industrial-technological and ecological-geographical.

Realisation of industrial and technological potential allows the territories to form additional arguments in favour of perspective development, and ecological and geographical potential helps cities to develop tourist and recreational sphere.

\section{Types of marketing for the cities}

The results of the analysis presented above allow us to conclude that the socio-economic conditions are a necessary but insufficient factor to disclose the marketing potential of cities. The existence of functioning mechanisms does not in itself make the city attractive to anyone, including local residents. In order for the territory's marketing 
potential to be disclosed, this requires not only capital investment and infrastructure management, but also marketing activity on behalf of the territory.

Widely known are the types of marketing used by market participants from the supply side, depending on the state of demand. Thus, if the demand is negative, conversion marketing tools are used, in the absence of demand, they try to stimulate it; in situations of demand fluctuations, synchromarketing mechanisms are launched; developing marketing is necessary to anticipate the appearance of the product on the market; falling demand makes remarketing necessary, and excessive demand forces to resort to demarketing.

Negative consumer demand is typical for extremely disadvantaged areas, that is zones of military conflicts, environmental disasters, man-made disasters. It is clear that it is extremely difficult to attract potential local residents, tourists, and residents to such territories. But still, history knows examples when even in the most unfavourable conditions territories managed to overcome resistance and negativity on the part of consumers.

After the cases of terrorist attacks against tourists in the state of Sri Lanka on 21 and 22 April 2019, the demand has become negative. To resume the tourist flow, the Sri Lankan authorities conducted an advertising campaign on the Russian market as one of the key ones, supported by attractive offers from private companies. Sri Lankan Airlines issued several special offers, hotels offered free group transfers, and the cost of living in some hotel complexes has decreased by $50 \%$. This made it possible to attract a significant number of tourists.

Special assistance programs, in which volunteers from the United States and other countries came to the city to participate in restoration work, helped to attract tourists to New Orleans. Many of them stayed in New Orleans, starting their own businesses. As a result, the city now has 300 more restaurants than in 2005.

It is estimated that in 2018 the number of tourists in the city reached 13.7 million people per year.

Thus, we can talk about successful conversion marketing territory.

It is necessary to understand that the efforts to attract any consumer groups to the territory, do always finally affect the local residents. Our discussions with colleagues during the preparation of this publication have made it even clearer for us that marketing potential of a territory should be defined as the ability to attract and retain the permanent population. Territories need investors, tourists, students, and so on in order to maintain the territory's opportunities for local residents at the proper level (job creation, landscaping, budget revenues).

Unfortunately, it should be noted that the cities of Siberia are in dire need of conversion marketing. Historical facts and relatively harsh climatic conditions make subjective risk assessments in business relations highly overestimated, and trends towards investing in Siberian enterprises - underestimated. The development of business and cultural contacts is hampered by "background" suspicion and pessimism (Lidin, Timofeev, Kalyuzhnova, 2004).

Incentive marketing is more likely to be effective if a company is able to clearly diagnose their competitive advantages and intensively promote them. In this case, we can cite the classic example of the city of Canton in the United States, which is not having a strong competitive advantage, however, has found a market niche. As the core, around 
which it was possible to create an attractive territorial product, it turned out to be just a clear sky - an ideal condition for Aeronautics (Vidyapin, Stepanov, 2007).

Synchromarketing is successfully used by tourist and recreational areas, the concepts of "high" and "low" season work. The main tool of this type of marketing is the price, with respect to which the priority of this element of the marketing mix remains.

Situations associated with the implementation of the developing type of marketing are most often encountered in the preparation of territories for large-scale event phenomena. For example, each Olympic capital of the upcoming games from the date of the announcement and up to the opening ceremony operates a mechanism of developing marketing: attracting labour for the construction of Olympic facilities, pre-sale of tickets, souvenirs, broadcasting rights etc.

Demarketing is increasingly becoming an object of study as a technology used by the territory. Already widely described has been the practice of its application in the state of California (USA), where for several decades there has been a ban on the expansion of water and energy infrastructure, in order to protect the densely populated coast from excessive construction of new housing. Comparatively recently, Barcelona (Spain) has joined the practice of demarketing. The city authorities for the sake of limiting the tourist flow imposed a ban on renting housing by non-residents: the issuance of licenses for the so-called tourist apartments was suspended. These include residential properties, equipped and prepared for immediate delivery entirely (and not separately in rooms), subject to rent two or more times a year, but for a period of not more than 31 days, information about which is posted on the channels for tourist use.

The classic of remarketing territories is the history of the city of Bonn. Bonn was the most inconspicuous, the most modest and the youngest European capital - in November 1949, by a majority of only 21 votes, the Bundestag decided in favour of Bonn (against Frankfurt am Main) as the temporary capital of the Federation. And after 42 years, Bonn lost the vote in the Bundestag - to the city's credit - by a majority of only seventeen votes, the Parliament and the government decided to move to Berlin, which became the official capital in 1990 under the Unification Treaty. Only a few ministries and Federal agencies remained in Bonn.

In 1994, the government adopted the "Berlin/Bonn Gesetz" - a law regulating the problems arising when moving the capital and defining the revival of Bonn in a new capacity. Seven ministries and many departments remained in Bonn, the rest retained their offices here.

The city became involved in the development of international programs and accepted the services of the UN. But most importantly, the city is becoming the centre of rapidly growing telecommunications and media organizations.

Another striking example is another European capital - London. Everyone knows their project of renovation of the docks, implemented in the 1980s. This venture was financed by large capital interested in moving out of the business districts. For this purpose, the special economic zone in which businessmen exempted from the property tax was created in the area, simplified coordination of planning decisions and many privileges on financing were provided.

It is noteworthy that the territories, which have long paid attention to the marketing aspects of their socio-economic development, in recent years have intensified their rebranding, which is one of the key tools of remarketing territories, provided that the 
Figure 2. Vectors of marketing types action on the life cycle curve of territorial products

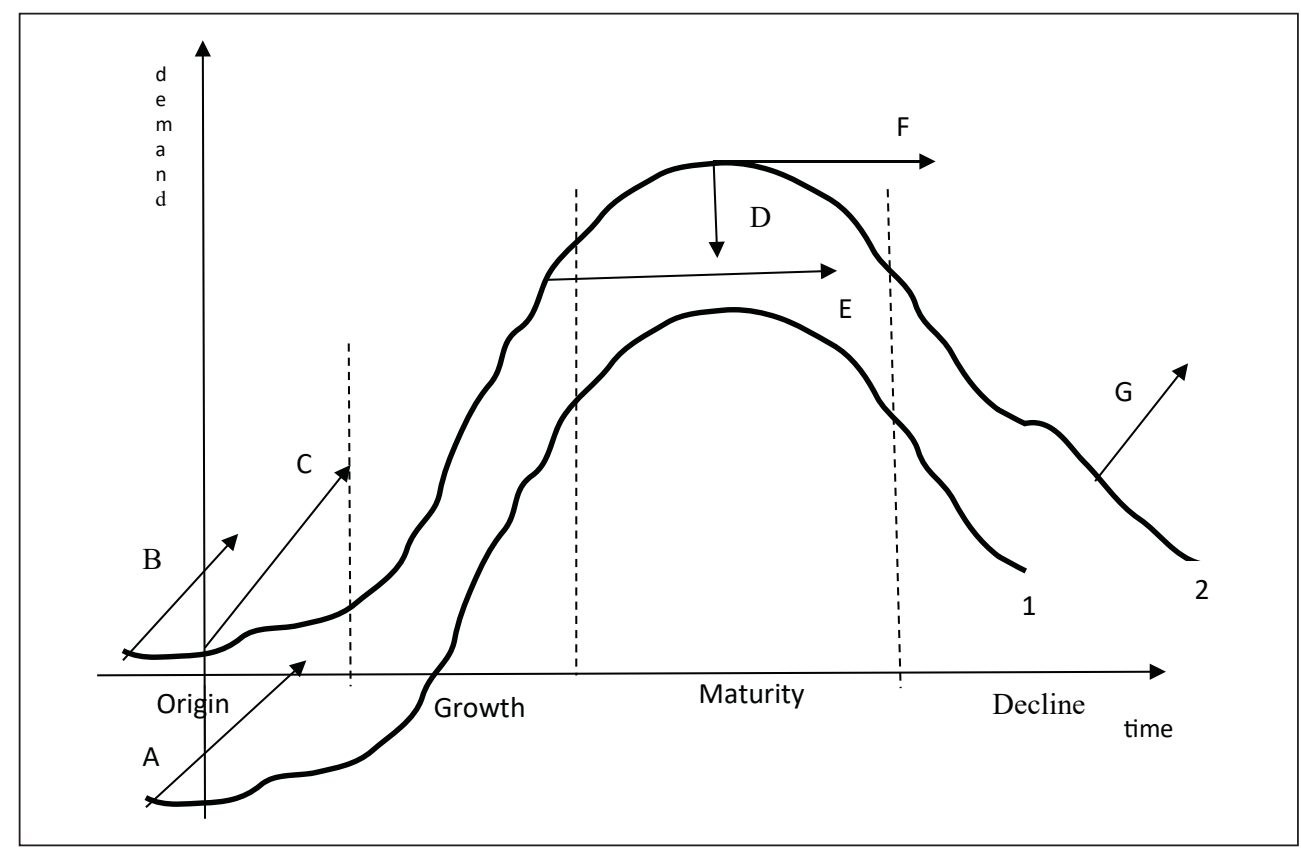

Source: authors' own work (2018)

actual branding was carried out before. In this regard, worth mentioning is the city of Amsterdam.

The rejection of the traditional images of the "three crosses", quite popular among the local population and business, became part of the policy to break the stereotypical idea of Amsterdam as a city of all-permissiveness. The peculiarity of the new brand, which distinguishes it from a number of others, is not a constructive and graphic solution at all, but "materialisation" in a real urban environment. The 'I love Amsterdam' logo has truly earned a reputation as the voluminous sculptures that have been installed in the city. They became a new attraction.

Of course, the most commonly used type of marketing is supportive. Many European cities are constantly promoting themselves, many tourist zones are constant in their communication activity.

It is known, that the demand for any products, including territorial, varies over time, forming a certain life cycle curve (Figure 2).

The first curve reflects the situation of negative demand for the territorial product, and the indicated vector of impact (a) is typical for conversion marketing. The second curve reflects the other types of marketing and their characteristic vectors of marketing efforts to regulate demand. Thus, situation B means developing marketing, which anticipates the release of the product to the market, situation $\mathrm{C}$ - stimulating marketing, D - demarketing, situation E describes the vector of action of supporting marketing, designed to keep demand at the achieved level, $\mathrm{F}$ - synchromarketing and situation $\mathrm{G}$ reflects the vector of marketing efforts in the implementation of remarketing. 


\section{SUMMARY AND CONCLUSION}

Summarising all the above, we can note that the socio-economic conditions of cities are arguments for the functioning of a territory. Traditionally, city authorities believe that it is necessary to work to improve these conditions, which is certainly true, but is not always enough to ensure a stable and/or growing demand from potential local residents. Therefore, we can determine the urgent need of marketing activity of the territory, like it takes place in business to generate demand. Business practice has gained extensive experience in applying marketing technologies, depending on the nature of demand.

As a result, it can be stated that the types of marketing in relation to territorial products have features associated with the scale of objects of market activity, at the same time, the vector of implementation in relation to demand coincides with the methods of traditional marketing.

Each type of marketing can have an impact on the disclosure of the marketing potential of the city, including from the point of view of the key consumer - a real or potential local resident, as well as other categories of consumers.

Marketing potential contributes to forming attractiveness of the territory for potential consumers, which in turn increases the economic cost of the system. In other words, the use of marketing tools adds additional consumer value to the territory in the form of attractiveness in the eyes of customers, which increases their number (residents, investors, tourists, etc.) and, as a result, provokes an increase in socio-economic effects.

\section{References}

Current Situation in the Rental Market in Barcelona. (2017). Retrieved from: https://www.homesoverseas.ru/articles/7750 (Accessed on: 2019, April 8) [in Russian].

Fedorovich, V.O. (2019). Improving the Marketing Potential of the Territories (For Example Siberian Federal District). Vestnik Akademii Znaniy, 4(33), 219-230 [in Russian].

Jakobson, A.Ya., Vikhoreva, M.V. (2019). Evaluating the marketing potential of socio-economic conditions of Irkutsk city. In: Geographical research of Siberia and adjacent territories. Materials of the International geographic conference dedicated to the 90th birthday of Academician Vladimir Vasilievich Vorobyev (October 21-25, 2019). Irkutsk: Publishing House of the V.B. Sochava Institute of Geography SB RAS [in Russian].

Kiryanova, L.G., Fedko, V.P. (2016). Methodological Support of Forming Marketing Concept of Realization of the Potential of a Territory as a "Growth Point". Global Research Potential, 12(69), 97-102.

Kuron, I. (1997). Stadtmarketing. Chance zur ganzheitlichen Stadtentwicklung. In: H. Pfaff-Schley (ed.) Stadtmarketing und kommunales Audit. Berlin: Springer, 1-14.

Lidin, K.L., Timofeev, I.A., Kalyuzhnova, N.V. (2004). The international image of Asian Russia and its role in creating the trans-Eurasian corridor. In: A.P. Khomenko (ed.) Geopolitical and socio-economic problems of creating international transport corridors. Irkutsk: IrGUPS, Book 2, 96-110 [in Russian].

London Docklands: From Slums to Skyscrapers. (2015). Real Estate Market Indicators. Retrieved from: https://www.redevelopment.irn.ru/articles/854.html (Accessed on: 2019, June 4) [in Russian].

Porter, M. (1990). The Competitive Advancement of Nations, New York: The Free Press [in Russian under the title Mezhdunarodnaya konkurentsiya, Moscow: Mezhdunarodnye Otnosheniya, 1993].

Tolstykh, D.V. (2013). Marketing Potential as the Factor of Socio-Economic Development of Territories. Moscow [in Russian, on the rights of the manuscript]. 
Traveling with a camera. (2015, April, 17). Bonn. Retrieved from: http://www.fotourizm.ru/ rasskasat/bonn (Accessed on: 2019, June 4) [in Russian].

Tselykh, T.N. (2016). The Dynamic Principle of Coherence Socio-Economic and Marketing Processes in the Formation of the Marketing Potential of the Territory. Vestnik Sibirskogo Instituta Biznesa i Informatsionnykh Tekhnologiy, 4(20), 59-66 [in Russian].

Vidyapin, V.I. Stepanov M.V. (2007). Regional Economics. Moscow: INFRA-M [in Russian].

Vizgalov, D.V. (2008). City Marketing. Practical Guide. Moscow: Fond "Institut Yekonomiki Goroda" [in Russian].

Vikhoreva, M.V. (2018). Types of marketing features of application of by territories. In: N.N. Danilenko, O.N. Baeva (eds.), Enhancing the intellectual and resource potential of the regions. Proceedings of the 4th All-Russian Scientific and Practical Conference. Irkutsk, the 17th of May, 2018. Part 1. Irkutsk: BSU publishing House [in Russian].

Anatol Jakobson, Doctor of Geographic Sciences, Professor, Irkutsk State Transport University, Chair "Management" (Head of the Chair in the years 2004-2016). Candidate of Geographic Sciences (PhD) since 1980, Doctor of Geographic Sciences since 1995. Research interests: economic regionalisation, foreign experience of regional policy (especially growth poles concept), urban systems in Siberia, environmental economic problems of the Baikal Region, railway management, regional marketing. Author of more than 250 published works.

\section{ORCID: https://orcid.org/0000-0003-3928-5405}

\section{Address:}

Irkutsk State Transport University

15 Chernyshesky St., 664074, Irkutsk, Russia

e-mail: anatoliy.jakobson@gmail.com

Mariya Vikhoreva, Candidate of Economic Sciences, Associate Professor (Docent), Irkutsk State Transport University, Chair "Management", Irkutsk, Russia. Maria Vikhoreva has been studying the problems of territorial marketing for many years. The author of more than 30 academic papers in this field. Considers territorial marketing as one of the areas of activity of authorities, is interested in revealing the marketing potential of territories from the point of view of a systematic approach.

ORCID: https://orcid.org/0000-0001-7555-6917

\section{Address:}

Irkutsk State Transport University

15 Chernyshesky St., 664074, Irkutsk, Russia

e-mail: vmv2000@mail.ru 